MATEUSZ GHOLAMY

Łódź

Uniwersytet Łódzki

ORCID: 0000-0002-9523-2116

DOI: $10.4467 / 12311960 M N .21 .015 .15243$

\title{
Rozwój wczesnych biologicznych metod leczenia schizofrenii po II wojnie światowej
}

\section{Development of early biological methods of treatment of schizophrenia after the II World War}

\begin{abstract}
Summary
The article tells about the history of development the first biological methods of treatment of schizophrenia, introduced after the II World War. At first, there was insulin shock therapy, introduced for the first time in 1933, then electroconvulsive therapy, applied in 1938 and lobotomy, which became popular method of treatment in 40s and 50s. Introducing every of this methods was an important step in schizophrenia research, altough all of them were mainly ineffective. Moreover all of this methods contain many side effects, even dangerous to life. It seems that development of each of this methods was crucial step important to introduce much more effective and safety ways of treatment of this disease.
\end{abstract}

Słowa kluczowe: historia psychiatrii, historia schizofrenii, biologiczne metody leczenia schizofrenii

Keywords: history of psychiatry, history of schizophrenia, biological methods of treatment of schizophrenia

II wojna światowa była w dziejach Europy i świata wydarzeniem przełomowym. Zmieniło się wtedy podejście do wielu kwestii cywilizacyjnych, a także związanych z nauką oraz sztuką. Nastąpił także bezprecedensowy w dotychczasowych dziejach rozwój techniki i medycyny. Także w psychiatrii nastąpiło $\mathrm{w}$ tym czasie bardzo wiele zmian. Podejście do leczenia schizofrenii się unowocześniło i wprowadzono 
szereg nowych biologicznych metod, które miały stać się skutecznym sposobem leczenia tej dotąd dosyć tajemniczej choroby ${ }^{1}$. Artykuł przedstawia pokrótce te metody, jednak z wyłączeniem farmakoterapii, gdyż, moim zdaniem, zasługuje ona na osobne omówienie.

\section{Leczenie wstrząsami insulinowymi}

Metodę wstrząsów insulinowych w leczeniu schizofrenii po raz pierwszy wprowadził w październiku 1933 r. Manfred Sakel, austriacki psychiatra, polsko-żydowskiego pochodzenia, pracujący w prywatnej klinice pod Berlinem (wcześniej stosował tę metodę w leczeniu uzależnienia od morfiny). Leczenie wspomnianą metodą odbywało się $\mathrm{w}$ specjalnych pomieszczeniach przy udziale dużego zespołu medycznego i polegało na podawaniu pacjentom dawek insuliny powodujących stan kompletnej nieświadomości. Najpierw podawano od 5 do 20 jednostek insuliny, aby wywołać stan senności (faza przygotowawcza), a następnie od 15 do nawet 500 jednostek w celu wywołania śpiączki (faza szokowa). Chorzy byli utrzymywani w tym stanie przez około 15 minut, maksymalnie do 20 minut (niekiedy jednak przedłużano śpiączkę nawet do 2 godzin $)^{2}$. Następnie wybudzano ich za pomocą stężonego roztworu glukozy podawanego zgłębnikiem do żołądka lub za pomocą zastrzyku glukozy. Cała terapia składała się z 50-60 takich cykli, w zależności od poprawy stanu psychicznego ${ }^{3}$.

Terapia ta była dość niebezpieczna. W jej trakcie pojawiały się objawy niepożądane w postaci bolesnych drgawek, niekiedy dochodziło także do zapaści spowodowanej wywołanym przez hipoglikemię niekontrolowanym spadkiem ciśnienia krwi i akcji serca. Śmiertelność wśród pacjentów leczonych tą metodą wynosiła od 1 do $5 \%$. W późniejszym okresie zaczęto stosować tzw. insulinę subkomatyczną, w której nie doprowadza się do śpiączki, tylko stanu głębokiego

\footnotetext{
${ }^{1}$ Należałoby też powiedzieć, że schizofrenia współcześnie nadal jest chorobą do pewnego stopnia tajemniczą. Ciągle nie za wiele wiemy o jej etiologii (poza tym toczą się w tej kwestii spory), mechanizmach neurobiologicznych (chociaż tutaj postęp jest znaczący, szczególnie jeśli chodzi o neurochemię schizofrenii, ale ciągle daleki od zadowalającego) czy stosowaniu jakichś skutecznych metod profilaktyki. Jednak, rzecz jasna, przyrost wiedzy, badań i literatury na temat schizofrenii jest dzisiaj ogromny i ciężko go porównać do sytuacji z lat 40 . XX w.

${ }^{2}$ E. Shorter, Historia psychiatrii: od zakładu dla obłakanych po ere Prozacu, Wydawnictwa Szkolne i Pedagogiczne, Warszawa 2005, s. 202.

${ }^{3} \mathrm{~K}$. Jones, Insulin coma therapy in schizophrenia, "Journal of The Royal Society of Medicine", Vol. 93, March 2000, s. 147.

${ }^{4}$ F.G. Ebaugh, A review of the drastic shock therapies in the treatment of the psychoses, "Annals of Internal Medicine" 1943, No. 18(3), s. 288.
} 


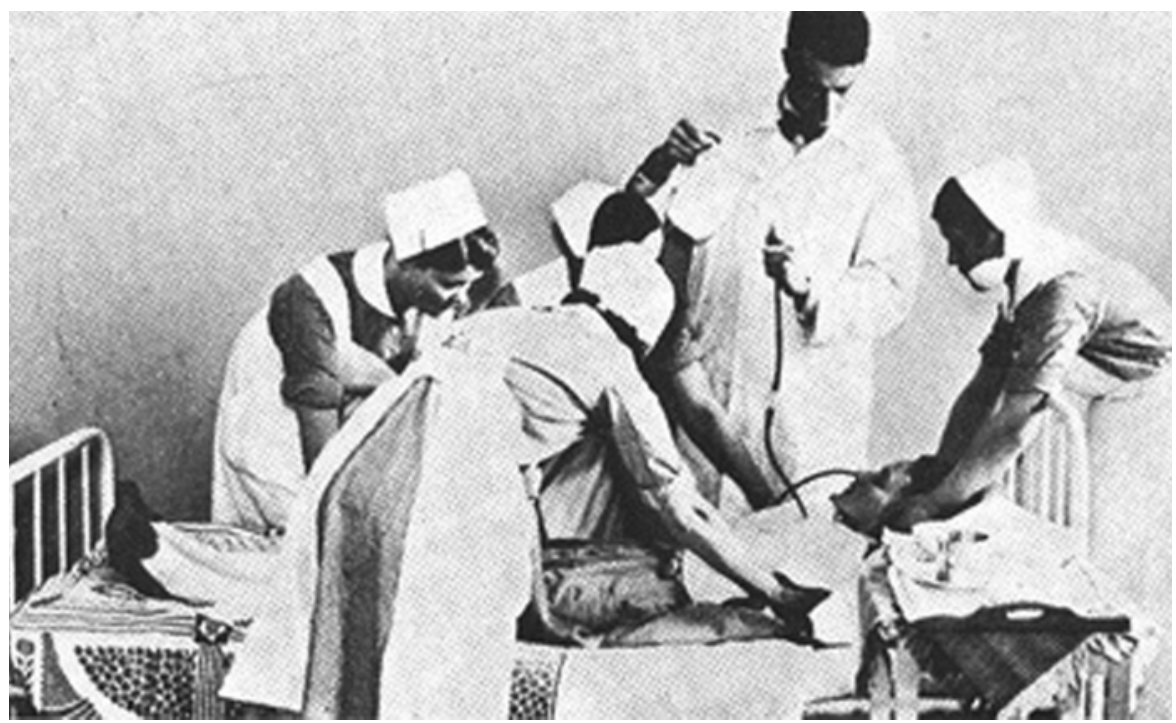

Rycina 1. Terapia śpiączką insulinową

Źródło: http://en.wikipedia.org/wiki/File:Insulin_shock_therapy.jpg [dostęp: 15.07.2020].

przymroczenia, aby nie powodować ryzyka zapaści i nieodwracalnej śpiączki ${ }^{5}$. Niektórzy pacjenci opisywali, jakim trudnym doświadczeniem było przeżycie terapii insulinowej, jeden z nich wspominał: „,́́niło mi się, że byłem na rollercoasterze, który znajdował się w piekle"6.

Metoda insulinowa szybko rozprzestrzeniła się właściwie w całej Europie. Do 1938 r. 31 szpitali w Anglii i Walii miało pomieszczenia do terapii insulinowej ${ }^{\dagger}$. W USA terapię tę zastosował po raz pierwszy Joseph Wortis (choć spopularyzował ją przebywający od 1936 r. w Nowym Jorku Manfred Sakel). Po II wojnie światowej terapia wstrząsami insulinowymi przeżyła swój rozkwit. W latach 40. i 50. była używana w większości szpitali w Wielkiej Brytanii i USA. W 1952 r. amerykański psychiatra dr Wilson powiedział, że „każdy szpital powinien mieć własne pomieszczenie do terapii insulinowej" ". Na początku lat 60 . specjalistyczne oddziały insulinoterapii znajdowały się w ponad 100 amerykańskich szpitalach psychiatrycznych ${ }^{9}$. Należy również dodać, że mniej więcej równolegle z pojawieniem i rozpowszechnieniem się metody wstrząsów insulino-

${ }^{5}$ A. Kępiński, Schizofrenia, Wydawnictwo Literackie, Kraków, 2001, s. 277.

${ }^{6}$ A. Hamlin, M.D. Starks, Subjective experiences in patients incidents to insulin and metrazol therapy, "Psychiat. Quart." 1938, No. 12(4), s. 699.

7 K. Jones, op. cit., s. 147.

${ }^{8}$ E. Shorter, op. cit., s. 208.

9 Ibidem, s. 148. 
wych pojawiały się w psychiatrii także różne inne metody wstrząsowe generowane chemicznie, głównie pod postacią wstrząsów kardiazolowych, ale też indoklonowych i kamforowych (te ostatnie powróciły do psychiatrii w 1933 r., po ponad 100 latach przerwy ${ }^{10}$ ).

W Polsce metoda wstrząsów insulinowych była poddawana badaniom i analizie w Klinice Neurologiczno-Psychiatrycznej w Wilnie od kwietnia 1935 r. Jednak wiodącym w Polsce ośrodkiem stosującym tę metodę stał się przed wojną Otwock, gdzie w szpitalu „Zofiówka” popularyzował ją Jakub Frostig. Warto też dodać, że Manfred Sakel współpracował z polskimi psychiatrami, gościł również na Zjeździe Psychiatrów Polskich w Gostyninie w czerwcu 1935 r., gdzie jego wystąpienie dotyczące wstrząsów insulinowych wywołało gorącą dyskusję ${ }^{11}$.

Powolny zmierzch terapii wstrząsami insulinowymi rozpoczął się, kiedy odkryto pierwsze leki przeciwpsychotyczne na początku lat 50 . Wśród wielu psychiatrów panowało jednak przekonanie, że leczenie insulinowe daje w schizofrenii lepsze wyniki niż leczenie neuroleptykami. Na początku lat 70. Antoni Kępiński, słynny polski psychiatra, pisał o swoich kolegach lekarzach tak: „mają oni nieraz poczucie winy, że chorego nie dość dokładnie leczyli, jeśli nie zastosowali u niego pełnych zapaści insulinowych" ${ }^{12}$. W 1957 r. w prestiżowym czasopiśmie medycznym „Lancet” opublikowano wyniki randomizowanych badań kontrolnych, które udowadniały, że insulina nie ma żadnego znaczenia w leczeniu schizofrenii ${ }^{13}$.

Metoda wstrząsów insulinowych przełamała terapeutyczny impas w psychiatrii i przybliżyła ją do medycyny głównego nurtu, szczególnie do neurologii. Wydzielenie specjalnych pomieszczeń, utworzenie specjalistycznych oddziałów i wykwalifikowanie odpowiedniego personelu nadawało nowej metodzie odpowiednią rangę. Niektóre pojedyncze przypadki spektakularnych wyleczeń z beznadziejnych schizofrenii także konstytuowało terapię wstrząsami insulinowymi. Również sami psychiatrzy poczuli się w końcu prawdziwymi lekarzami, a nie tylko „doradcami psychicznymi”. Te wszystkie czynniki sprawiły, że pomimo raczej niskiej skuteczności i obecności groźnych działań niepożądanych tej terapii była ona przez wiele lat bardzo popularna.

${ }^{10}$ T. Zyss, R.T. Hesse, A. Zięba, Terapia wstrzasowa w psychiatrii - rys historyczny, „Psychiatria Polska” 2008, t. 42, nr 6, s. 799.

${ }^{11}$ R. Kujawski, Pierwsze pięć lat insulinoterapii schizofrenii w Polsce (1935-1939), „Psychiatria i Psychoterapia” 2015, t. 11, nr 2, s. 42.

${ }_{12}$ A. Kępiński, op. cit., s. 278.

${ }^{13}$ B. Ackner, A. Harris, A.J. Oldham, Insulin treatment of schizophrenia; a controlled study, "Lancet" 1957, Mar. 23, No. 272(6969), Abstract. 


\section{Elektrowstrząsy}

Kolejną biologiczną metodą leczenia schizofrenii wprowadzoną do psychiatrii głównie po II wojnie światowej były elektrowstrząsy. Terapia elektrowstrząsowa została zastosowana po raz pierwszy w kwietniu 1938 r. przez Ugo Cerlettiego, profesora psychiatrii z Rzymu, kierownika Kliniki Chorób Nerwowych i Umysłowych przy Uniwersytecie Rzymskim ${ }^{14}$. Zanim jednak do tego doszło, Cerletti razem ze swoimi asystentami Ferdinando Accornera, Lucio Binim i Lamberto Longhim od października 1936 r. prowadził eksperymenty z wywoływaniem drgawek u psów, a następnie u świńn ${ }^{15}$.

Pierwszy aparat do elektrowstrząsów, umożliwiający przesłanie w ułamku sekundy prądu elektrycznego o napięciu 80-100 woltów, skonstruował przy pomocy technika Lucio Bini. Pierwszy pacjent leczony elektrowstrząsami przeszedł 11 serii zabiegów za pomocą elektrod przyłożonych do skroni i został wypisany ze szpitala w „dobrym stanie ogólnym” (wcześniej cierpiał na halucynacje) ${ }^{16}$. Elektrowstrząsy dzięki swojej skuteczności, przy względnym bezpieczeństwie i niskich kosztach stosowania, w bardzo krótkim czasie rozprzestrzeniły się jako metoda w wielu krajach, będąc w latach 40. i 50. jednym z najważniejszych sposobów leczenia stosowanych w psychiatrii. Stało się tak także za sprawą Lothara Kalinowsky'ego, niemiecko-żydowskiego psychiatry, który spopularyzował tę metodę w różnych krajach Europy, a potem w USA (choć elektrowstrząsy w USA wprowadził jako pierwszy Renato Almansi $)^{17}$.

W tym czasie pacjent chory na schizofrenię miał do wyboru trzy metody leczenia: wstrząsy insulinowe, lobotomię i elektrowstrząsy.

Elektrowstrząsy nie były jednak wówczas całkowicie bezpieczne. Wywoływały drgawki, które mogły doprowadzić do złamania kończyn i kręgów. W tym celu przy zabiegu od 1940 r. stosowano kurarę, która rozluźniała napięte mięśnie kończyn. W 1952 r. kurarę zastąpiono sukcynylocholiną, zaczęto także stosować podczas terapii elektrowstrząsowej znieczulenie ogólne, do którego używano głównie soli sodowej metoheksytalu ${ }^{18}$.

${ }^{14}$ E. Shorter, op. cit., s. 239.

${ }^{15}$ Ibidem, s. 239-240.

${ }^{16}$ Ibidem, s. 242.

17 Z.M. Lebensohn, The History of Electroconvulsive Therapy In the United States and Its Place In American Psychiatry: A Personal Memoir, „Comprehensive Psychiatry", Vol. 40, No. 3, May/June 1999, Abstract.

${ }_{18}$ T. Zyss, R.T. Hesse, A. Zięba, op. cit., s. 810. 
Coraz silniejsza pozycja psychoanalizy w psychiatrii, rozwój farmakoterapii chorób psychicznych (farmakoterapia zaczęła dość szybko wypierać inne metody biologiczne, w tym elektrowstrząsy), ale chyba przede wszystkim działalność ruchu antypsychiatrycznego i wykreowanie przez niego negatywnego obrazu elektrowstrząsów w społeczeństwie i kulturze sprawiło, że od początku lat 60 . do końca 70. utrzymywał się obraz tej metody jako niehumanitarnej czy wręcz barbarzyńskiej. Powstało w tym czasie wiele mitów na temat elektrowstrząsów, stały się one na poziomie społecznym negatywnym symbolem represji i bezradności lecznictwa psychiatrycznego ${ }^{19}$. Do $1980 \mathrm{r}$. ich zastosowanie spadło o $46 \%{ }^{20}$.

Od lat 80. obserwuje się jednak ponowny wzrost zainteresowania elektrowstrząsami i powolną rehabilitację tej metody. Zwieńczeniem tego procesu jest raport Amerykańskiego Towarzystwa Psychiatrycznego z 2001 r., który uwypukla znaczenie elektrowstrząsów we współczesnej medycynie ${ }^{21}$.

Sam Cerletti stosował elektrowstrząsy w leczeniu schizofrenii. Potem były one stosowane także w leczeniu depresji. Od lat 90. elektrowstrząsy stosuje się głównie w leczeniu depresji lekoopornej z powodu nietolerancji leków przeciwdepresyjnych, przy dobrej odpowiedzi na poprzednie elektrowstrząsy, oraz jako „ostatnią deskę ratunku” (przy współwystępowaniu w depresji stanów psychotycznych i dużym ryzyku samobójstwa). Zmieniły się także wskazania w zakresie elektrowstrząsowego leczenia schizofrenii. Obecnie elektrowstrząsy w leczeniu schizofrenii stosuje się raczej rzadko jako metodę pierwszego rzutu. Są one wykorzystywane głównie w leczeniu schizofrenii lekoopornej, a także schizofrenii przebiegającej z groźnym dla życia osłupieniem lub pobudzeniem (tzw. schizofrenia katatoniczna). W tej ostatniej uzyskuje się podobno znaczące efekty już po zastosowaniu 2-3 zabiegów ${ }^{22}$.

\footnotetext{
${ }^{19}$ Jednym z najważniejszych przykładów takiego demonizowania elektrowstrząsów w kulturze była książka Kena Keseya Lot nad kukułczym gniazdem z 1962 r. (w swojej wymowie antypsychiatryczna), na podstawie której w 1975 r. Milos Forman nakręcif film pod tym samym tytułem. Jego (i jej) główny bohater Randle McMurphy jest poddawany w szpitalu psychiatrycznym elektrowstrząsom, które przypominają nie zabieg medyczny, tylko okrutne tortury.

${ }^{20} \mathrm{http}$ ://psychology.about.com/od/eindex/g/electroconvulsive-therapy.htm [dostęp: 15.08.2020].

${ }^{21}$ E. Shorter, The History of ECT: Some Unsolved Mysteries, "Psychiatric Times", February 2004, s. 96.

${ }^{22}$ M. Dąbrowski, T. Parnowski, Analiza kliniczna skuteczności i bezpieczeństwa leczenia elektrowstrzasowego, „Psychiatria Polska” 2012, t. XLVI, nr 3, s. 351.
} 


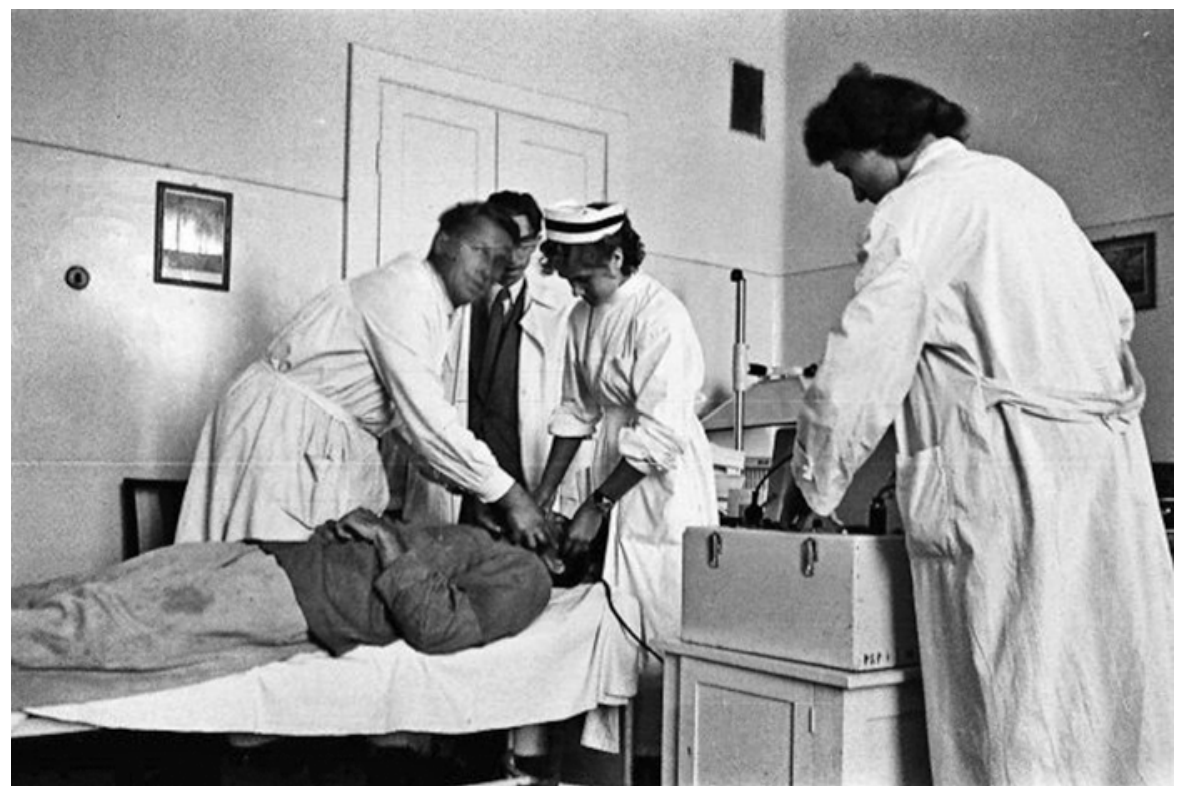

Rycina 2. Terapia elektrowstrząsowa

Źródło: http://bi.gazeta.pl/im/7/11828/z11828377Q,Elektrowstrzasy-jako-metoda-lecznicza.jpg [dostęp: 17.07.2020].

W 2003 r. amerykański National Institute for Health and Clinical Excellence (NICE) przestał rekomendować elektrowstrząsy w leczeniu schizofrenii, podpierając się metaanalizą pokazującą brak korzyści lub nieznaczną korzyść w porównaniu z placebo, a także w porównaniu z kombinacją leków przeciwpsychotycznych, w tym klozapiną ${ }^{23}$.

W ostatnim czasie powstało wiele prac dotyczących działań niepożądanych elektrowstrząsów i ich wpływu, wskutek długotrwałego stosowania, na pamięć, ogólne zdolności poznawcze, strukturę mózgu oraz ciążę. Ich wyniki wciąż są niejednoznaczne i wymagają dalszych badań i analiz. Panuje jednak zgoda, że istnieje pewne zagrożenie w stosowaniu elektrowstrząsów związane $\mathrm{z}$ anestezją przed zabiegiem i ryzykiem sercowym u pacjentów leczonych tą metodą ${ }^{24}$. Można jednak w podsumowaniu powiedzieć, że współcześnie elektrowstrząsy są generalnie bezpieczną metodą leczenia, a w niektórych stanach (jak katatonia czy depresja lekooporna) są wręcz terapią ratującą życie.

${ }^{23}$ P. Tharyan, C.E. Adams, Electroconvulsive Therapy for Schizophrenia, 2005, Cochrane Schizophrenia Group, Abstract.

${ }^{24}$ http://www.theuniversityhospital.com/ect/effects.htm [dostęp: 25.06.2020]. 
Wciąż także nie jest znany do końca mechanizm działania elektrowstrząsów. Cerletti swoją metodę opierał na obserwacji antagonizmu między padaczką a schizofrenią. Obecnie uważa się, że terapia elektrowstrząsowa powoduje zmniejszenie liczby receptorów beta-adrenergicznych przy jednoczesnej modyfikacji ich gęstości (beta-downregulacja). Jest to efekt bardzo podobny do tego, jaki obserwujemy przy długo działającym leczeniu lekami przeciwdepresyjnymi. Badania na zwierzętach wykorzystujące tzw. zwierzęce modele depresji wykazały zmniejszenie i normalizację nadaktywnych połączeń neuronalnych w hipokampie, strukturze układu limbicznego odpowiedzialnej między innymi za pamięć i emocje ${ }^{25}$.

\section{Psychochirurgia (lobotomia) i jej rozkwit w latach 40. i 50.}

Ostatnią biologiczną metodą leczenia schizofrenii stworzoną po II wojnie światowej (oczywiście wyłączając farmakoterapię) była lobotomia. Za twórcę lobotomii, czy inaczej leukotomii przedczołowej, uważa się portugalskiego neurologa Antonio Egasa Moniza. Bezpośrednią inspiracją do zainicjowania przez niego zabiegów były badania Johna Fultona i Carlyle'a Jacobsena na temat zmian emocjonalnych dwóch szympansów o imieniu Becky i Lucy, wskutek wycięcia płatów czołowych. Obserwowali oni, jak agresywne i uparte małpy po operacji stawały się spokojne i wesołe. Moniz zetknął się z pracami Fultona i Jacobsena podczas ich referatów w trakcie całodniowego sympozjum poświęconego czołowym płatom mózgu, odbywającego się w Londynie w 1935 r. w ramach II Międzynarodowego Kongresu Neurologicznego ${ }^{26}$.

Nie można jednak twierdzić, że wyłącznie te badania doprowadziły do rozpoczęcia wdrażania lobotomii u ludzi. W połowie lat 30 . badania nad płatami czołowymi mózgu były bardzo popularne, a sam Moniz był zapoznany $\mathrm{z}$ różnymi innymi pracami na ten temat ${ }^{27}$. Twierdził ponadto, że neurobiologicznym modelem różnych chorób psychicznych nie są nieprawidłowości w budowie struktur mózgu ani neuronów, tylko nieprawidłowe, „splątane” połączenia między nimi (odnosił to szczególnie do połączeń płatów czołowych z innymi obszarami mózgu) ${ }^{28}$.

${ }^{25} \mathrm{http}$ ://biotechnologia.pl/biotechnologia-portal/info/bioetyka/30_aktualnosci /368913,elektrowstrzasy_czy_naprawde_strach_sie_bac_html [dostęp: 27.06.2020].

${ }^{26}$ A.C. Heller, A.P. Amar, C.Y. Liu, M.L.J. Apuzzo, Surgery of the mind and mood: A mosaic of issues in time and evolution, "Neurosurgery" 2006, No. 59(4), s. 727.

${ }_{27}$ J.D. Pressman, Last Resort: Psychosurgery and the Limits of Medicine, Cambridge University Press, 2002, s. 53.

${ }^{28}$ R.P. Feldman, J.T. Goodrich, Psychosurgery: A Historical Overview, „Neurosurgery”, March 2001, No. 48 (3), s. 651. 
Moniz nie był także pierwszym badaczem, który eksperymentował z lobotomią na ludziach. W 1932 r. francuski lekarz Maurice Ducoste wstrzykiwał do płatów czołowych $5 \mathrm{ml}$ krwi zakażonej malarią ponad 100 swoim pacjentom przez otwory wydrążone w czaszce ${ }^{29}$. W Szwajcarii równolegle $\mathrm{z}$ eksperymentami Moniza Francois Ody usunął cały prawy płat czołowy u pacjenta ze schizofrenią katatoniczną ${ }^{30}$.

Jednak za właściwy początek stosowania lobotomii w psychiatrii uważa się 12 listopada 1935 r., kiedy to Moniz wraz ze swoim współpracownikiem Almeidą Limą zaczęli przeprowadzać w szpitalu Santa Marta w Lizbonie szereg zabiegów na chorych psychicznie pacjentach. Na po-

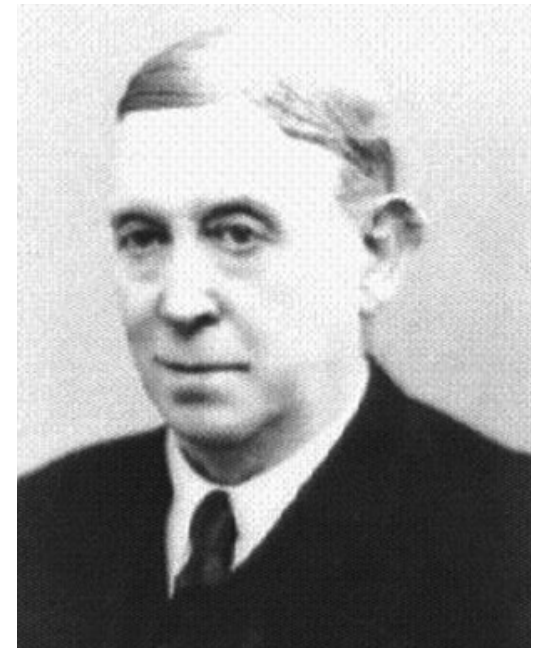

Rycina 3. Antonio Egas Moniz (1874-1955)

Źródło: http://faculty.washington. edu/chudler/gif/moniz.jpg [dostęp: 30.07.2020]. czątku operacji przeprowadzano u chorych trepanację czaszki, a następnie wstrzykiwano etanol do korowej istoty białej obszarów czołowych (etanol miał za zadanie niszczenie połączeń neuronalnych obszarów czołowych z układem limbicznym) ${ }^{31}$. Pierwszą pacjentkę, cierpiącą na depresję, po przeprowadzeniu zabiegu uznano za całkowicie zdrową, choć w praktyce do końca życia pozostała w szpitalu psychiatrycznym ${ }^{32}$.

W trakcie wykonywania lobotomii Moniz zmienił technikę ich przeprowadzania. Zaczął używać przyrządu chirurgicznego zwanego leukotomem. Leukotom zakończony był wirującą pętlą, która tworzyła celowe uszkodzenia o średnicy około 1 centymetra w istocie białej płatów czołowych ${ }^{33}$. Do lutego 1936 r. Moniz przeprowadził 20 loboto-

${ }^{29}$ E.S. Valenstein, The Prefrontal Area and Psychosurgery, "Progress in Brain Research" 1990, Vol. 85, s. 541.

${ }^{30}$ E.G. Berrios, The Origins of Psychosurgery: Shaw, Burckhardt and Moniz, "History of Psychiatry" 1997, No. 8(1), s. 77.

${ }^{31}$ E. Moniz, Prefrontal Leucotomy in the Treatment of Mental Disorders (1937), “American Journal of Psychiatry 1844-1944" 1994, s. 237.

${ }^{32}$ R.P. Feldman, J.T. Goodrich, Psychosurgery: A Historical Overview, "Neurosurgery”, March 2001, No. 48(3), s. 651.

${ }^{33}$ D. Gross, G. Schafer, Egas Moniz and the "invention" of modern psychosurgery: a historical and ethical reanalysis under special consideration of Portuguese original sources, "Neurosurgical Focus" 2011, No. 30(2), s. 2. 
mii, w tym 6 na pacjentach chorych na schizofrenię ${ }^{34}$. Wśród działań niepożądanych po zabiegach obserwowano m.in.: nietrzymanie moczu i stolca, biegunki, wymioty, a także szereg zmian w funkcjonowaniu psychoruchowym i poznawczym, apatię, letarg, akinezję oraz dezorientację $e^{35}$. Jednak pomimo tych konsekwencji Moniz uważał swoją metodę za skuteczną i bezpieczną, pisząc $\mathrm{w}$ czasopismach fachowych o 14 na 20 całkowicie wyleczonych pacjentach ${ }^{36}$. Sam mówił o lobotomii w następujących słowach: „lobotomia jest prostą operacją, zawsze bezpieczną, która może udowodnić znaczenie leczenia chirurgicznego w niektórych przypadkach chorób psychicznych"37. Na początku środowisko medyczne odnosiło się do nowej metody dosyć sceptycznie. Na przykład Sobral Cid, psychiatra, który na początku wspierał Moniza, przekazując mu swoich pacjentów z prywatnego szpitala w Lizbonie, mówił z czasem o „degradacji osobowości” u osób po lobotomii ${ }^{38}$.

W Wielkiej Brytanii do 1942 r. przeprowadzono tylko 6 lobotomii, podobnie było $\mathrm{w}$ innych krajach ${ }^{39}$. Wyjątkiem były Włochy, gdzie zabieg ten był bardzo popularny. W centrum włoskiej lobotomii, szpitalu Racconigi pod Turynem, do wybuchu II wojny światowej przeprowadzono około 200 takich operacji ${ }^{40}$.

W 1936 r. Walter Freeman i James Watts przeprowadzili pierwszą lobotomię w USA (Freeman bardzo interesował się osiągnięciami Moniza, prowadził z nim także korespondencję dotyczącą wdrażania nowej metody w Ameryce $)^{41}$. Freeman dążył do uproszczenia procedury tak, aby nie tylko wykwalifikowani neurochirurdzy, ale każdy psychiatra mógł bez trudu przeprowadzać ten zabieg. W ten sposób przeprowadził w 1948 r. po raz pierwszy tzw. lobotomię transorbitalną. Zastąpił znieczulenie pacjentów elektrowstrząsami, a operację przeprowadzał, wbijając chorym w mózg, przez kości oczodołowe, zmodyfikowany szpikulec do rozbijania lodu, nazwany przez niego orbitoklastem (wcześniej ćwiczył swój pomysł w kuchni na grejpfrutach $)^{42}$.

${ }^{34}$ E.G. Berrios, op. cit., s. 75.

${ }^{35}$ D. Gross, G. Schafer, op. cit., s. 3.

${ }^{36}$ R.P. Feldman, J.T. Goodrich, op. cit., s. 652.

${ }^{37}$ E. Moniz, op. cit., s. 237.

${ }^{38}$ Z. Kotowicz, Psychosurgery in Italy 1936-39, „History of Psychiatry”, December 2008, No. 19(4), s. 482.

${ }^{39}$ Ibidem, s. 476-477.

40 Ibidem, s. 477.

${ }^{41}$ J.D. Pressman, op. cit., s. 78.

${ }^{42} \mathrm{http}$ ://www.npr.org/2005/11/16/5014080/my-lobotomy-howard-dullys-journey [dostęp: 27.06.2020]. 
Lobotomia rozpowszechniła się w USA po II wojnie światowej przez zalew amerykańskich weteranów, którzy wypełniali zatłoczone szpitale psychiatryczne. Biuro do spraw weteranów rozesłało w 1943 r. do oddziałów terenowych rozporządzenie, w którym żądało, aby wszyscy neurochirurdzy odbyli przeszkolenie w zakresie lobotomii ${ }^{43}$. Sam Freeman także bardzo przyczynił się do popularyzacji nowej metody. Miał osobowość tzw. showmana i lubił zwracać na siebie uwagę. Podróżował niczym wędrowny artysta po całym USA swoim samochodem, który nazwał lobotomobilem, aby wykonywać spektakularne zabiegi i kształcić swoich następców (popisując się przed publicznością wykonywał na przykład dwie lobotomie jednocześnie, każdą inną ręką). Za każdy zabieg pobierał 25 dolarów. Witały go zazwyczaj rzesze ludzi, tytuły prasy lokalnej anonsowały wizytę, często trafiał do popularnych amerykańskich magazynów, jak „Time” czy „Life”44.

W 1949 r. przeprowadzono w USA rekordową liczbę 5074 zabiegów. W tym samym roku Antonio Egas Moniz otrzymał Nagrodę Nobla z dziedziny medycyny i fizjologii za „odkrycie terapeutycznego znaczenia lobotomii w określonych psychozach" (zmarł w 1955 r., w momencie kiedy jego metoda zaczęła okrywać się złą sławą). Do $1951 \mathrm{r}$. w USA przeprowadzono operację na 18608 osobach $^{45}$.

Ogromną liczbę lobotomii przeprowadzano także w Skandynawii. W Szwecji pomiędzy rokiem 1944 a 1966 przeprowadzono przynajmniej 4500 takich zabiegów, w tym na małych dzieciach ${ }^{46}$. W Polsce w latach 1947-1951 przeprowadzono 176 lobotomii (głównie w szpitalu w Kościanie, ale też w Warcie, Kochanówce i Gostyninie) ${ }^{47}$.

Wprowadzenie pierwszego neuroleptyku, chloropromazyny i coraz silniejsza krytyka lobotomii w kręgach medycznych na początku lat 50 . spowodowały, że zabieg ten szybko stawał się coraz mniej popularny, aż w końcu praktycznie kompletnie zaniechano jego stosowania ${ }^{48}$.

Dziś można stwierdzić, że wszystkie osoby poddane operacjom w obrębie płatów czołowych cierpiały potem na tzw. zespół czołowy,

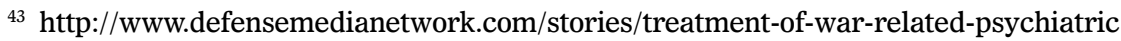
-injuries-post-world-war-ii/ [dostęp: 29.06.2020].

${ }^{44} \mathrm{http}$ ://scienceblogs.com/neurophilosophy/2007/07/24/inventing-the-lobotomy/ [dostęp: 2.07.2020].

${ }^{45}$ E. Shorter, op. cit., s. 250.

${ }^{46}$ K. Ogren, M. Sandlund, Psychosurgery in Sweden 1944-1964, "Journal of the History of the Neurosciences" 2005, No. 14(4), Abstract.

${ }^{47}$ K. Jęczmińska, History of lobotomy in Poland, „History of psychiatry”, Vol. 29, Iss. 1 , s. 7.

${ }^{48}$ E. Shorter, op. cit., s. 250. 


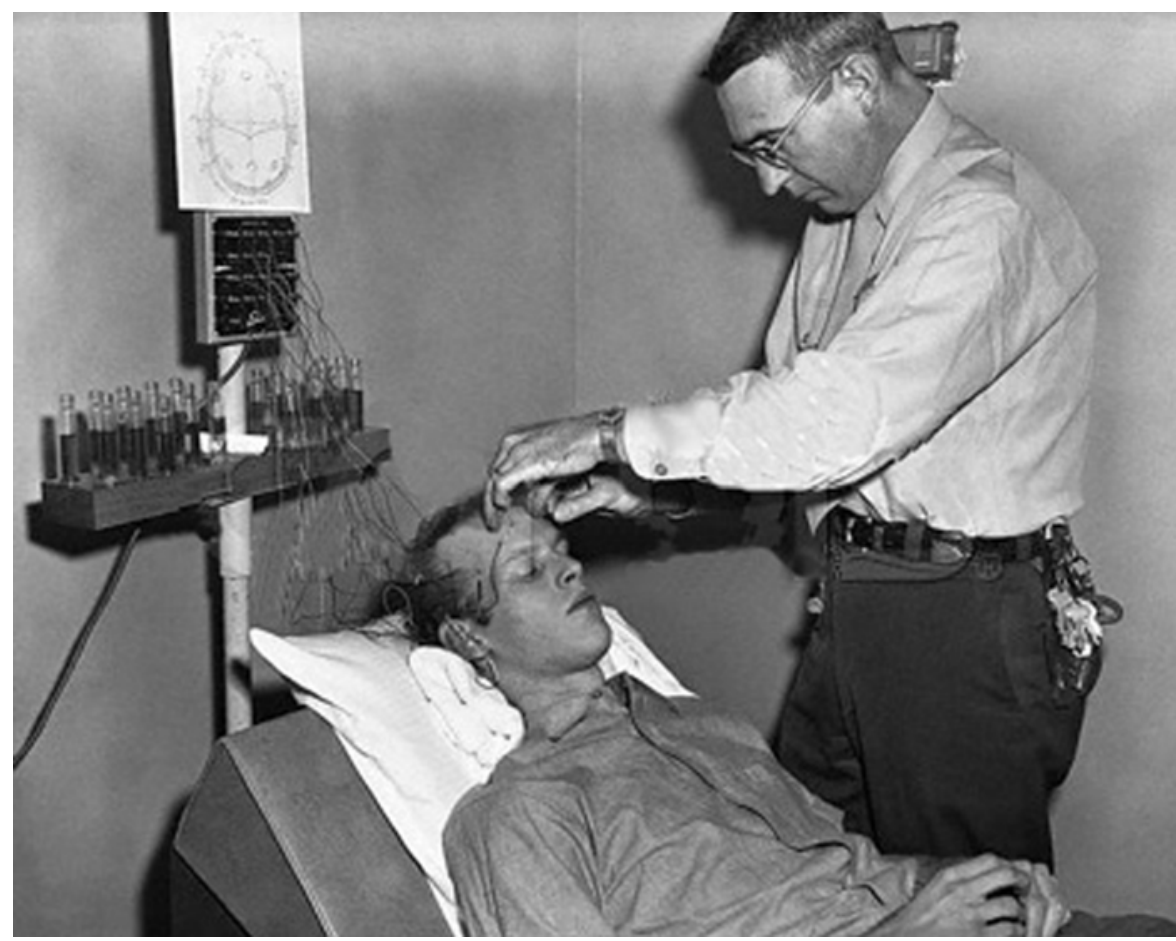

Rycina 4. Walter Freeman (1895-1972) podczas wykonywania jednego ze swoich zabiegów

Źródło: http://www.newsweek.pl/bins/Media/Pictures/67/6752/6752a5b43f8d4bf4b53fa3af0f0dc76e.jpg [dostęp: 26.07.2020].

padaczkę pooperacyjną, a także ulegały deterioracji intelektualnej. Płaty czołowe odpowiadają za realizację wyższych czynności psychicznych i intelektualnych, w tym za myślenie abstrakcyjne, planowanie, przewidywanie, motywację, a także odpowiedzialność i kontrolę niższych czynności psychicznych. Wyłączenie ich funkcji, przez zniszczenie połączeń płatów czołowych z innymi częściami mózgu, powodowało $\mathrm{u}$ chorych dezorganizację osobowości oraz praktycznie zupełne pozbawienie motywacji, a u osób pobudzonych zahamowanie zachowań instynktownych i popędowych. Obserwowano także zaburzenia nastroju, apatię, obojętność, zaburzenia samokontroli zachowań, ogólny zanik emocjonalności, zanik więzi z najbliższymi oraz trudności w planowaniu i myśleniu abstrakcyjnym.

Lobotomię przeprowadzono $\mathrm{w}$ sumie na około 70 tys. ludzi. $67 \%$ z nich po zabiegu zamieniło się w „bezwolne warzywa”, kilka procent 
zmarło z powodu wylewu krwi do mózgu ${ }^{49}$. Reszta została w istotny sposób trwale okaleczona emocjonalnie i intelektualnie (wśród nich m.in. siostra prezydenta USA Johna F. Kennedy'ego, Rosemary Kennedy) ${ }^{50}$.

Rozwój nowych biologicznych metod leczenia schizofrenii po II wojnie światowej utorował drogę farmakoterapii, która miała stać się w przyszłości o wiele skuteczniejszą, bezpieczniejszą i zdecydowanie wiodącą metodą leczenia tej choroby, jak zresztą większości innych chorób psychicznych.

\section{Bibliografia}

\section{Książki i czasopisma}

Ackner B., Harris A., Oldham A.J., Insulin treatment of schizophrenia; a controlled study, "Lancet" 1957, t. 272, nr 6969.

Berrios E.G., The Origins of Psychosurgery: Shaw, Burckhardt and Moniz, "History of Psychiatry" 1997, t. 8, nr 1.

Dąbrowski M., Parnowski T., Analiza kliniczna skuteczności i bezpieczeństwa leczenia elektrowstrzasowego, „Psychiatria Polska” 2012, t. 46, nr 3.

Ebaugh F.G., A review of the drastic shock therapies in the treatment of the psychoses, “ Annals of Internal Medicine” 1943, t. 18, nr 3.

Feldman R.P., Goodrich J.T., Psychosurgery: A Historical Overview, „Neurosurgery” 2001, t. 48, nr 3.

Gross D., Schafer G., Egas Moniz and and the "invention" of modern psychosurgery: a historical and ethical reanalysis under special consideration of Portuguese original sources, "Neurosurgical Focus” 2011, t. 30, nr 2.

Hamlin A., Starks M.D., Subjective experiences in patients incidents to insulin and metrazol therapy, "Psychiatric Quarterly" 1938, t. $12, \mathrm{nr} 4$.

Heller A.C., Amar A.P., Liu C.Y., Apuzzo M.L.J., Surgery of the mind and mood: A mosaic of issues in time and evolution, "Neurosurgery" 2006, t. 59, nr 4.

Jones K., Insulin coma therapy in schizophrenia, "Journal of The Royal Society of Medicine” 2000, t. 93.

Kępiński A., Schizofrenia, Kraków 2001.

\footnotetext{
49 http://historia.newsweek.pl/rozpruwacze-ludzkich-mozgow,84685,4,1.html [dostęp: 4.07.2020].

so http://www.guardian.co.uk/world/2009/aug/13/eunice-kennedy-shriver-rosemary-kennedy [dostęp: 5.07.2020].
} 
Kotowicz Z., Psychosurgery in Italy 1936-39, „, History of Psychiatry” 2008, t. 19, nr 4.

Lebensohn Z.M., The History of Electroconvulsive Therapy in the United States and its Place in American Psychiatry: A Personal Memoir, „Comprehensive Psychiatry” 1999, t. 40, nr 3.

Moniz E., Prefrontal Leucotomy in the Treatment of Mental Disorders (1937), "American Journal of Psychiatry" 1994, t. 151, nr 6.

Ogren K., Sandlund M., Psychosurgery in Sweden 1944-1964, "Journal of the History of the Neurosciences" 2005, t. 14, nr 4.

Pressman J.D., Last Resort: Psychosurgery and the Limits of Medicine, Cambridge 2002.

Shorter E., The History of ECT: Some Unsolved Mysteries, "Psychiatric Times" 2004, t. 21, nr 2.

Shorter E., Historia psychiatrii: od zakładu dla obłakanych po ere Prozacu, Warszawa 2005.

Tharyan P., Adams C.E., Electroconvulsive Therapy for Schizophrenia-Cochrane Database of Systematic Reviews, New Jersey 2005.

Valenstein E.S., The Prefrontal Area and Psychosurgery, "Progress in Brain Research" 1990, t. 85.

Zyss T., Hesse R.T., Zięba A., Terapia wstrzasowa w psychiatrii - rys historyczny, "Psychiatria Polska" 2008, t. 42, nr 6.

\section{Strony internetowe}

http://psychology.about.com/od/eindex/g/electroconvulsive-therapy. html.

http://biotechnologia.pl/biotechnologia-portal/info/bioetyka/30_aktualnosci/368913,elektrowstrzasy_czy_naprawde_strach_sie_bac_html.

http://www.npr.org/2005/11/16/5014080/my-lobotomy-howard-dullys-journey.

http://www.defensemedianetwork.com/stories/treatment-of-warrelated-psychiatric-injuries-post-world-war-ii/.

http://scienceblogs.com/neurophilosophy/2007/07/24/inventing-thelobotomy/.

http://historia.newsweek.pl/rozpruwacze-ludzkich-mozgow,84685,4,1. html.

http://www.guardian.co.uk/world/2009/aug/13/eunice-kennedy-shriver-rosemary-kennedy. 